\title{
Exome, transcriptome and miRNA analysis don't reveal any molecular markers of TKI efficacy in primary CML patients
}

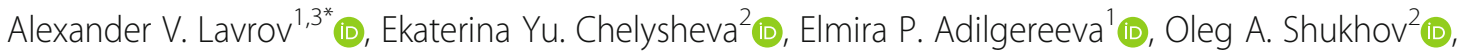
Svetlana A. Smirnikhina ${ }^{1} \mathbb{D}$, Konstantin S. Kochergin-Nikitsky ${ }^{1}$ (D), Valentina D. Yakushina ${ }^{1} \mathbb{D}$, Grigory A. Tsaur ${ }^{4,5,6} \mathbb{D}^{\mathbb{D}}$, Sergey V. Mordanov ${ }^{7}$ (D) Anna G. Turkina ${ }^{2}$ (i) and Sergey I. Kutsev ${ }^{1,3}$ (i)

From 11th International Multiconference "Bioinformatics of Genome Regulation and StructurelSystems Biology" - BGRSISB2018

Novosibirsk, Russia. 20-25 August 2018

\begin{abstract}
Background: Approximately 5-20\% of chronic myeloid leukemia (CML) patients demonstrate primary resistance or intolerance to imatinib. None of the existing predictive scores gives a good prognosis of TKI efficacy. Gene polymorphisms, expression and microRNAs are known to be involved in the pathogenesis of TKI resistance in CML. The aim of our study is to find new molecular markers of TKI therapy efficacy in CML patients.

Methods: Newly diagnosed patients with $\mathrm{Ph}+\mathrm{CML}$ in chronic phase were included in this study. Optimal and non-optimal responses to TKI were estimated according to ELN 2013 recommendation. We performed genotyping of selected polymorphisms in 62 blood samples of CML patients, expression profiling of 33 RNA samples extracted from blood and miRNA profiling of 800 miRNA in 12 blood samples of CML patients.

Results: The frequencies of genotypes at the studied loci did not differ between groups of patients with an optimal and non-optimal response to TKI therapy. Analysis of the expression of 34,681 genes revealed 26 differently expressed genes $(p<0.05)$ in groups of patients with different TKI responses, but differences were very small and were not confirmed by qPCR. Finally, we did not find difference in miRNA expression between the groups.

Conclusions: Using modern high-throughput methods such as whole-exome sequencing, transcriptome and miRNA analysis, we could not find reliable molecular markers for early prediction of TKI efficiency in Ph+CML patients.
\end{abstract}

Keywords: Chronic myeloid leukemia, TKI efficacy, Exome, Transcriptome, miRNA analysis

\footnotetext{
* Correspondence: alexandervlavrov@gmail.com

'Laboratory of Mutagenesis, Federal State Budgetary Institution, Research

Centre for Medical Genetics, Moskvorechie str., 1, Moscow, Russian

Federation 115522

${ }^{3}$ Department of Molecular and Cellular Genetics, State Budgetary Educational

Institution of Higher Professional Education "Russian National Research

Medical University named after N.I. Pirogov" of Ministry of Health of the

Russian Federation, Ostrovityanova str., 1, Moscow, Russian Federation 117997

Full list of author information is available at the end of the article
}

(c) The Author(s). 2019 Open Access This article is distributed under the terms of the Creative Commons Attribution 4.0 International License (http://creativecommons.org/licenses/by/4.0/), which permits unrestricted use, distribution, and reproduction in any medium, provided you give appropriate credit to the original author(s) and the source, provide a link to the Creative Commons license, and indicate if changes were made. The Creative Commons Public Domain Dedication waiver (http://creativecommons.org/publicdomain/zero/1.0/) applies to the data made available in this article, unless otherwise stated. 


\section{Introduction}

Chronic myeloid leukemia (CML) is a clonal myeloproliferative disorder characterized by the presence of $[9 ; 22]$ translocation and $B C R / A B L$ fusion gene with high tyrosine kinase activity which activates MAPK pathway, cell proliferation, blocks apoptosis and leads to genome instability resulting in further development of the disease. Imatinib, BCR/ABL tyrosine kinase inhibitor (TKI) is the standard therapy in CML-Ph+ patients since its FDA approval in 2001. Patient's survival improved from 7.5 years after diagnosis before imatinib era to 17.5 years now-a-days [1].

Despite high efficacy of imatinib the problem of primary resistance persists. Based on the recent report about $21 \%$ of CML patients are switched to another TKI because of resistance or intolerance [2]. According to other authors approximately 20 to $30 \%$ of patients develop resistance to imatinib [3].

At the same time hematologists have limited instruments to determine which patients will have primary resistance to imatinib and may benefit from other treatment regimens or use of newly developed TKIs as the 1st line therapy. Sokal and Hasford scores were developed in pre-imatinib era and now poorly predict the outcomes of the TKI therapy while EUTOS score gives more reliable prediction [4]. However in some studies it was estimated that all three scoring systems didn't work correctly to predict complete cytogenetic response and survival with imatinib treatment, especially in non-European populations $[5,6]$. Currently, the main trend to predict the better outcome is to use the rule "deeper and earlier response" [7], but this approach allows only late prediction after starting the therapy.

Different genetic factors are known to be associated with primary imatinib resistance $[8,9]$. A variety of polymorphisms and mutations in genes associated with TKI resistance was reported [10-12]. Recently we have performed whole-exome sequencing in primary CML patients before TKI administration and revealed five genetic variants typical for optimal responders (rs11579366 in ANKRD35, rs1990236 in DNAH9, rs176037 in MAGEC1, rs10653661 in TOX3, rs3803264 in THSD1) and two - for non-optimal responders (rs3099950 in MORN2, rs9471 966 in PTCRA) [13].

Among other factors gene expression differences are of a particular interest since expression profiling was demonstrated to be a valuable prognostic tool in many types of cancer. It was previously shown that expression levels of several genes differ between groups with different responses to TKI therapy $[14,15]$. Frank et al. demonstrated that $C O C H, A N A P C 5$ and TPSAB1/B2 were overexpressed in imatinib non-responders while VNN1 and $R P H 3 A$ were down-regulated. The magnitude of differences was dramatically low - fold change varied from
0.547 to 1.487 and was confirmed by qRT-PCR for only two genes. However 128-gene expression signature was successfully used to correctly classify the subset of test samples [14].

MircoRNAs (miRNAs) are small (18-25 nucleotides in length) non-coding RNAs which regulate gene expression by translational repression or mRNA cleavage [16]. Previously obtained data shows that miRNAs are involved in CML pathogenesis: some miRNAs are up-regulated and some are down-regulated in the peripheral blood of CML patients [17-20]. Moreover, there is data supporting the idea of different expression levels of miRNAs in CML patients with good and poor response to TKI therapy. San José-Enériz et al. [21] performed analysis of expression profiles of 250 miRNAs in bone marrow mononuclear cells from patients with $\mathrm{Ph}+$ CML at diagnoses and showed that 19 miRNAs were differentially expressed in resistant and responder samples. Similar study was performed in peripheral blood samples by microarray analysis in two groups of patients - with response and resistance to TKI. Authors identified 70 differently expressed miRNAs between these groups [22]. In both studies cluster unsupervised analysis of obtained expression levels of miRNAs was able to distinguish clearly both groups. It was also shown that miR-30 reduces $B C R / A B L$ mRNA and protein levels by binding directly to the $A B L$ 3'UTR and increases sensitivity of BCR/ABL-positive cells to imatinib. CML patients expressing low levels of miR-30 were less sensitive to imatinib [23]. High expression of miR-424 suppressed proliferation and induced apoptosis of K562 cells thereby increased sensitivity to imatinib treatment [24]. In another work it was shown that miR-26a, miR-29c, miR-130b and miR-146a were down-regulated in imatinib resistant patients in comparison to responders [25].

Despite the variety of the approaches and findings at DNA and RNA levels none of the potential markers were validated or implemented in clinical practice. The aim of our study is to find new molecular markers of TKI therapy efficacy in CML patients.

\section{Materials and methods \\ Patients}

Newly diagnosed patients with $\mathrm{Ph}+\mathrm{CML}$ in chronic phase were included in this study. Patients were recruited in the National Research Center for Hematology (Moscow), Regional Children Hospital \#1 (Ekaterinburg), Research Institute of Medical Cell Technologies (Ekaterinburg) and Rostov State Medical University (Rostov-on-Don). The study was performed according to the provisions of the Declaration of Helsinki. Informed consent was obtained from all patients included in this study. European LeukemiaNet (ELN) Recommendations for Management of CML [26] were followed to form criteria of 
- optimal response at 6 month: BCR-ABL ${ }^{\mathrm{IS}}<1 \%$ and/ or $0 \% \mathrm{Ph}+$ metaphases out of at least 20 or more bone marrow cells;

- non-optimal response: BCR-ABL ${ }^{\text {IS }} 1-10 \%$ and/or > $1 \% \mathrm{Ph}+$ metaphases out of at least 20 or more bone marrow cells at 6 months.

\section{Genotyping of CML patients}

Direct DNA Sanger sequencing of PCR products was performed as described previously [13]. Briefly, DNA from peripheral blood samples was obtained from CML patients before TKI therapy. Sequencing was performed using ABI Prism 3130XL genetic analyzer (Applied Biosystems, Foster City, CA) with either forward or reverse primer.

\section{Transcriptome and Bioinformatic analysis}

Blood samples were collected in Paxgene tubes (Becton, Dickinson and Company, USA) at diagnosis before initiating TKI therapy. RNA was extracted using PAXgene Blood RNA Kit (Qiagen, Germany) according to the manufacture's protocol. Expression profiling was performed using HumanHT Expression BeadChip (Illumina). Data analysis was performed in GenomeStudio_GX_Module (Illumina) and Partek Genomics Suite (Partek).

\section{miRNA and Bioinformatic analysis}

Total RNA was extracted from blood samples and lymphocytes cell cultures obtained before beginning the therapy at the time of diagnosis CML. RNA from Paxgene tubes (Becton, Dickinson and Company, USA) was extracted using PAXgene Blood RNA Kit (Qiagen, Germany) according to the manufacture's protocol; RNA from cell cultures was extracted by standard phenolchloroform method. miRNA profiling of 800 miRNA was done with nCounter miRNA Expression Assay (Nanostring Technologies) according to the manufacturer's protocol. Data analysis was performed in nSolver (Nanostring Technologies).

\section{Real-time reverse transcriptase-polymerase chain reaction} cDNA synthesis was performed using M-MuLV (SibEnzyme, Russia) with random hexa-primers. For validation of transcriptome findings cDNA $(3 \mu \mathrm{l})$ was added to the reaction mixture $(25 \mu \mathrm{l})$ containing $300 \mathrm{nM}$ primers, $200 \mu \mathrm{M}$ deoxynucleotide triphosphate, $1 \times$ working solution of SYBR Green I for $A C T B$ and $B 2 M$ genes (Invitrogene, USA), or $0.3 \mu \mathrm{M}$ TaqMan probe for $U B A 52, A T G 7$, PRR13 and DAZAP2 genes and 0.04 U Taq-polymerase. Real-time PCR was performed on a CFX96 system (Bio-Rad, USA). The reaction protocol was as follows: 5 min at $95^{\circ} \mathrm{C}$ and 40 cycles $\left(10 \mathrm{~s}\right.$ at $95^{\circ} \mathrm{C}, 10 \mathrm{~s}$ at $65^{\circ} \mathrm{C}$, $10 \mathrm{~s}$ at $70^{\circ} \mathrm{C}$ ). For DAZAP2 gene protocol was as follows: $3 \mathrm{~min}$ at $95^{\circ} \mathrm{C}$ and 40 cycles $\left(10 \mathrm{~s}\right.$ at $95^{\circ} \mathrm{C}, 10 \mathrm{~s}$ at
$60{ }^{\circ} \mathrm{C}, 20 \mathrm{~s}$ at $70^{\circ} \mathrm{C}$ ). List of primers is presented in (Additional file 1: Table S1). The relative amount of mRNA UBA52, ATG7, PRR13 and DAZAP2 was calculated by standardized expression $(\triangle \triangle \mathrm{C}(\mathrm{t}))$ for gene $A C T B$. The calculations were performed using CFX96 software (Bio-Rad, USA).

\section{Statistical analysis}

Statistical calculations were performed using STATISTICA 64 ver.13 (Dell Inc., USA), MS Office Excel, and SPSS Statistics 21.0. Chi-square tests were used to process the obtained genotyping data. A significance level of 0.05 was set and Bonferroni correction for multiple comparisons was applied. Mann-Whitney U test for the two independent groups was used for expression data analysis, patients' characteristics and comparison of numbers of obtained genetic variants. Haplotypes analysis was performed using R Haplo.stats [27]. Analysis of variance (ANOVA) and pathway enrichment analysis were performed in GenomeStudio_GX_Module (Illumina) and Partek Genomics Suite (Partek).

\section{Results}

Whole exome sequencing (WES) was used to find new potential markers of TKI efficacy [Lavrov AV, 2016]. With the aim of finding new molecular markers of failure of the TKI therapy we performed validation of the WES findings, transcriptome and miRNA analyses.

\section{Prognostic role of the polymorphisms in cancer- associated genes}

Seven variants were found to associate with the TKI efficacy in a small group of CML patients: rs115 79366 (in ANKRD35 gene), rs1990236 (DNAH9), rs176037 (MAGEC1), rs10653661 (TOX3), rs3803264 (THSD1), rs3099950 (MORN2), and rs9471966 (PTCRA). To validate these possible prognostic markers 62 patients with $\mathrm{Ph}+\mathrm{CML}$ in chronic phase were enrolled in the study. Median age was 46 years (range 19-71). Female:male ratio was 1:1.3. Fifty-nine patients received first-line therapy and three - second-line due to intolerance to imatinib or sub-optimal response at 3 months. According to ELN 2013 recommendations [26] at 6 months of TKI treatment all patients were divided into two groups - with optimal $(n=32)$ and non-optimal $(n=30)$ response to targeted therapy. Description of genotyped patients is available in Table 1.

The results of the genotyping of all the patients are summarized in Table 2. The frequencies of genotypes at the studied loci did not differ between groups of patients with an optimal and non-optimal response to TKI therapy.

Since genotype rates for individual genes did not demonstrate significant differences between groups of patients 
Table 1 Characteristics of the genotyped patients

\begin{tabular}{|c|c|c|c|}
\hline & $\begin{array}{l}\text { Patients with } \\
\text { optimal response } \\
\text { at } 6 \text { months } \\
(n=32)\end{array}$ & $\begin{array}{l}\text { Patients with } \\
\text { non-optimal } \\
\text { response at } \\
6 \text { months }(n=30)\end{array}$ & $p$-value \\
\hline Age, years, median (range) & $39(19-66)$ & $52(21-71)$ & 0.0768 \\
\hline Gender & & & 0.5940 \\
\hline Female, n (\%) & 15 (55.6) & $12(44.4)$ & \\
\hline Male, n (\%) & $17(48.6)$ & $18(51.4)$ & \\
\hline \multicolumn{4}{|l|}{ Sokal group } \\
\hline Low, n (\%) & $21(65.6)$ & $4(13.3)^{*}$ & \\
\hline Intermediate, n (\%) & $6(18.8)$ & $1(3.3)^{*}$ & \\
\hline High, n (\%) & $5(15.6)$ & $2(6.7)^{*}$ & \\
\hline \multicolumn{4}{|l|}{ TKI therapy } \\
\hline First line, n (\%) & $29(90.6)$ & $30(100)$ & \\
\hline Imatinib 400 mg, n (\%) & $25(78.1)$ & $28(93.3)$ & \\
\hline Imatinib 600 mg, n (\%) & & $2(6.7)$ & \\
\hline $\begin{array}{l}\text { Nilotinib 400-600 mg, } \\
\text { n (\%) }\end{array}$ & $3(9.4)$ & & \\
\hline Dasatinib, 100 mg, n (\%) & $1(3.1)$ & & \\
\hline Second line, n (\%) & $3(9.4)$ & $0(0)$ & \\
\hline $\begin{array}{l}\text { Nilotinib 400-600 mg, } \\
\text { n (\%) }\end{array}$ & $1(3.1)^{* *}$ & & \\
\hline Dasatinib, 100 mg, n (\%) & $2(6.3)^{* *}$ & & \\
\hline
\end{tabular}

*Sokal score data for 23 patients were not available **patients were switched to the second line therapy due to imatinib intolerance or sub-optimal response at 3 months

TKI tyrosine kinase inhibitor with optimal and non-optimal response to TKI, we analyzed whether there is an association of response to therapy with haplotypes (different combinations of alleles in selected genes). There was no reliable association with the therapy response of any of the haplotypes presented in patients $(p=0.94)$. Correction by gender and age also did not change the result.

\section{Transcriptome analysis}

Thirty-three $\mathrm{Ph}+\mathrm{CML}$ patients with the follow-up period more than 6 months were treated in National Research Center for Hematology (Moscow). Most of the patients demonstrated good response to the TKI therapy. However, five didn't have optimal response. All of them had $>10 \% \mathrm{Ph}+$ cells at 6 months (according to ELN2013 recommendations non-optimal response). We also chose 7 patients with optimal response for the comparison. Patient ages ranged from 20 to 77 years, with a median of 37 years. All 12 patients were treated by TKIs: 10 patients treated by imatinib, 2 patients by nilotinib. Detailed characteristics of these patients are available in Table 3.

ANOVA analysis of the expression of 34,681 genes revealed 26 differently expressed genes $(p<0.05)$ in patients with optimal and non-optimal responses (Table 4). Ten of these genes (DAZAP2, UBA52, PRR13, ATG7, LOC387820, PAK1, RAB11A, EMP3, GSTM1, GSTM2) are associated with other cancers and another four (RSAD2, MAP3K11, COMMD1, TNFRSF1A) are the key members of regulatory pathways including NF-kappa-B, MAPK, JNK and other thought to be disbalanced in many cancers (see Table 4).

Table 2 Rates of genotypes of analyzed genes in groups of patients with optimal and non-optimal response to TKI therapy

\begin{tabular}{|c|c|c|c|c|c|c|c|c|c|c|}
\hline \multirow{3}{*}{$\begin{array}{l}\text { Gene and reference SNP } \\
\text { ANKRD35 } \\
\text { rs11579366 }\end{array}$} & \multirow{3}{*}{$\begin{array}{l}\text { Reference allele } \\
\text { G }\end{array}$} & \multirow{3}{*}{$\begin{array}{l}\text { Variant allele } \\
\text { C }\end{array}$} & & \multicolumn{3}{|c|}{$\begin{array}{l}\text { Patients with optimal } \\
\text { response at } 6 \text { months }(n=32)\end{array}$} & \multicolumn{3}{|c|}{$\begin{array}{l}\text { Patients with non-optimal } \\
\text { response at } 6 \text { months }(n=30)\end{array}$} & \multirow{2}{*}{$\frac{p \text {-value }}{0,16}$} \\
\hline & & & genotype & $\mathrm{G} / \mathrm{G}$ & $\mathrm{G} / \mathrm{C}$ & $\mathrm{C} / \mathrm{C}$ & $\mathrm{G} / \mathrm{G}$ & $\mathrm{G} / \mathrm{C}$ & $C / C$ & \\
\hline & & & rate, $\%$ & 9 & 50 & 41 & 29 & 39 & 32 & \\
\hline \multirow{2}{*}{$\begin{array}{l}\text { DNAH9 } \\
\text { rs1990236 }\end{array}$} & G & A & genotype & $\mathrm{G} / \mathrm{G}$ & $\mathrm{G} / \mathrm{A}$ & $\mathrm{A} / \mathrm{A}$ & $\mathrm{G} / \mathrm{G}$ & $\mathrm{G} / \mathrm{A}$ & $\mathrm{A} / \mathrm{A}$ & 0,33 \\
\hline & & & rate, $\%$ & 72 & 22 & 6 & 57 & 39 & 4 & \\
\hline \multirow{2}{*}{$\begin{array}{l}\text { MAGEC1 } \\
\text { rs176037 }\end{array}$} & C & $\mathrm{T}$ & genotype & $C / C$ & $C / T$ & $\mathrm{~T} / \mathrm{T}$ & $\mathrm{C} / \mathrm{C}$ & $C / T$ & $\mathrm{~T} / \mathrm{T}$ & 0,68 \\
\hline & & & rate, $\%$ & 53 & 20 & 27 & 41 & 32 & 27 & \\
\hline \multirow[t]{2}{*}{$\begin{array}{l}\text { TOX3 } \\
\text { rs } 10653661\end{array}$} & A & ATTCT & genotype & $\mathrm{A} / \mathrm{A}$ & $\mathrm{A} / \mathrm{ATTCT}$ & $\begin{array}{l}\text { АTTCT/ } \\
\text { АTाTCT }\end{array}$ & $\mathrm{A} / \mathrm{A}$ & A/ ATाTCT & $\begin{array}{l}\text { ATTTCT/ } \\
\text { ATTCT }\end{array}$ & 0,87 \\
\hline & & & rate, $\%$ & 22 & 56 & 22 & 23 & 50 & 27 & \\
\hline \multirow{2}{*}{$\begin{array}{l}\text { THSD1 } \\
\text { rs3803264 }\end{array}$} & G & A & genotype & $\mathrm{G} / \mathrm{G}$ & $\mathrm{G} / \mathrm{A}$ & $\mathrm{A} / \mathrm{A}$ & $\mathrm{G} / \mathrm{G}$ & $\mathrm{G} / \mathrm{A}$ & $\mathrm{A} / \mathrm{A}$ & 0,38 \\
\hline & & & rate, $\%$ & 6 & 44 & 50 & 12 & 27 & 61 & \\
\hline \multirow{2}{*}{$\begin{array}{l}\text { MORN2 } \\
\text { rs3099950 }\end{array}$} & G & A & genotype & $\mathrm{G} / \mathrm{G}$ & $\mathrm{G} / \mathrm{A}$ & $\mathrm{A} / \mathrm{A}$ & $\mathrm{G} / \mathrm{G}$ & $\mathrm{G} / \mathrm{A}$ & $\mathrm{A} / \mathrm{A}$ & 0,48 \\
\hline & & & rate, $\%$ & 69 & 31 & 0 & 77 & 23 & 0 & \\
\hline \multirow{2}{*}{$\begin{array}{l}\text { PTCRA } \\
\text { rs9471966 }\end{array}$} & G & A & genotype & $\mathrm{G} / \mathrm{G}$ & $\mathrm{G} / \mathrm{A}$ & $\mathrm{A} / \mathrm{A}$ & $\mathrm{G} / \mathrm{G}$ & $\mathrm{G} / \mathrm{A}$ & $\mathrm{A} / \mathrm{A}$ & 0,88 \\
\hline & & & rate, $\%$ & 56 & 38 & 6 & 50 & 43 & 7 & \\
\hline
\end{tabular}


Table 3 Characteristics of patients for transcriptome study

\begin{tabular}{llllll}
\hline Patient & Gender & Age, years & Sokal score & TKI first line, dosage & Response to TKI \\
\hline 1 & Male & 36 & Intermediate risk & Imatinib, $400 \mathrm{mg}$ & Optimal response \\
2 & Female & 27 & High risk & Imatinib, $600 \mathrm{mg}$ & Optimal response \\
3 & Female & 57 & Low risk & Imatinib, $400 \mathrm{mg}$ & Optimal response \\
4 & Female & 55 & Low risk & Imatinib, $400 \mathrm{mg}$ & Optimal response \\
5 & Female & 68 & Intermediate risk & Imatinib, $400 \mathrm{mg}$ & Non-optimal response \\
6 & Male & 77 & Low risk & Imatinib, $400 \mathrm{mg}$ & Optimal response \\
7 & Male & 34 & Intermediate risk & Imatinib, $400 \mathrm{mg}$ & Non-optimal response \\
8 & Male & 20 & Low risk & Nilotinib, $600 \mathrm{mg}$ & Optimal response \\
9 & Female & 30 & Low risk & Imatinib, $400 \mathrm{mg}$ & Non-optimal response \\
10 & Male & 30 & High risk & Nilotinib, $800 \mathrm{mg}$ & Non-optimal response \\
11 & Female & 63 & Intermediate risk & Imatinib, $400 \mathrm{mg}$ & Non-optimal response \\
12 & Female & 38 & Low risk & Imatinib, $400 \mathrm{mg}$ & Optimal response \\
\hline
\end{tabular}

TKI tyrosine kinase inhibitor

Pathway enrichment analysis of the differently expressed genes showed the following molecular networks involved $(p<0.05)$ : glutathione metabolism, drug and xenobiotic metabolism, chemical mutagenesis, glycosaminoglycan degradation and MAPK signaling pathway. According to the expression levels we may suggest that these pathways are activated in patients who failed to achieve optimal response to TKI therapy.

From the list of the genes associated with cancers we selected first four with the largest difference in expression levels and analyzed their expression with RT-PCR: DAZAP2, UBA52, PRR13 and ATG7. Expression of these genes was measured in the same samples as whole transcriptome analysis and additional 10 samples from optimal responders were added. All the tested genes demonstrated similar differences in expression levels in optimal vice non-optimal responders as in whole transcriptome analysis (Table 4), however these differences were not significant (ANOVA, $p=0.3$ ).

\section{miRNA analysis}

After transcriptome analysis we focused on miRNA expression in patients with different TKI efficacy. We had already 140 patients with the follow-up period more than 6 months treated in three Hospitals in Russia. According to ELN2013 recommendations we selected 6 patients with optimal response and 6 patients with failure of the TKI therapy. Patient ages ranged from 20 to 89 years, with a median of 52.5 years. All 12 patients were treated with $400 \mathrm{mg}$ imatinib. Detailed characteristics of

Table 4 Differently expressed genes involved in cancers or regulatory pathways in optimal and non-optimal responders

\begin{tabular}{|c|c|c|c|c|}
\hline Gene & Localization & Gene description & Coefficient & RT-PCR, $x$ \\
\hline$D A Z A P 2$ & $12 \mathrm{q} 12$ & DAZ-associated protein 2 & -2.14 & -1.16 \\
\hline UBA52 & 19p13.1-p12 & Ubiquitin A-52 residue ribosomal protein fusion product 1 & -1.86 & -1.47 \\
\hline PRR13 & $12 \mathrm{q} 12$ & Proline rich 13 & -1.58 & -1.52 \\
\hline ATG7 & $3 p 25.3$ & Autophagy related 7 & -1.52 & -2.13 \\
\hline LOC387820 & $11 \mathrm{q} 24.3$ & DnaJ (Hsp40) homolog, subfamily B, member 7 pseudogene & 1.51 & \\
\hline PAK1 & $11 q 13-q 14$ & p21 protein (Cdc42/Rac)-activated kinase 1 & 1.52 & \\
\hline COMMD1 & $2 p 15$ & Copper metabolism (Murr1) domain containing 1 & 1.54 & \\
\hline$R A B 11 A$ & $15 q 22.31$ & Member RAS oncogene family & 1.55 & \\
\hline EMP3 & $19 q 13.3$ & Epithelial membrane protein 3 & 1.76 & \\
\hline RSAD2 & $2 \mathrm{p} 25.2$ & Radical S-adenosyl methionine domain containing 2 & 1.83 & \\
\hline MAP3K11 & $11 \mathrm{q} 13.1-\mathrm{q} 13.3$ & Mitogen-activated protein kinase kinase kinase 11 & 1.83 & \\
\hline GSTM1 & $1 p 13.3$ & Glutathione S-transferase mu 1 & 1.95 & \\
\hline GSTM2 & $1 \mathrm{p} 13.3$ & Glutathione S-transferase mu 2 (muscle) & 2.01 & \\
\hline TNFRSFIA & $12 \mathrm{p} 13.2$ & Tumor necrosis factor receptor superfamily, member $1 \mathrm{~A}$ & 2.02 & \\
\hline
\end{tabular}


Table $\mathbf{5}$ Characteristics of patients for miRNA study

\begin{tabular}{llllll}
\hline Patient & Gender & Age, years & Sokal score & TKI first line, dosage & Efficient TKI \\
\hline 3 & Female & 57 & Low risk & Imatinib, $400 \mathrm{mg}$ & Optimal response \\
5 & Female & 68 & Intermediate risk & Imatinib, $400 \mathrm{mg}$ & Non-optimal response \\
7 & Male & 34 & Intermediate risk & Imatinib, $400 \mathrm{mg}$ & Non-optimal response \\
12 & Female & 38 & Low risk & Imatinib, $400 \mathrm{mg}$ & Optimal response \\
13 & Female & 26 & Low risk & Imatinib, $400 \mathrm{mg}$ & Optimal response \\
14 & Male & 56 & Low risk & Imatinib, $400 \mathrm{mg}$ & Optimal response \\
15 & Female & 65 & Low risk & Imatinib, $400 \mathrm{mg}$ & Optimal response \\
16 & Female & 32 & High risk & Imatinib, $400 \mathrm{mg}$ & Optimal response \\
17 & Male & 44 & Low risk & Imatinib, $400 \mathrm{mg}$ & Non-optimal response \\
18 & Female & 89 & Low risk & Imatinib, $400 \mathrm{mg}$ & Non-optimal response \\
19 & Female & 63 & Intermediate risk & Imatinib, $400 \mathrm{mg}$ & Non-optimal response \\
20 & Male & 49 & Intermediate risk & Imatinib, $400 \mathrm{mg}$ & Non-optimal response \\
\hline
\end{tabular}

these patients are available in Table 5. All patients with therapy failure had $>10 \% \mathrm{Ph}+$ cells at 6 months in bone marrow. Four patients were included in both transcriptome and miRNA analysis (\#3, 5, 7, and 12 in Tables 3 and 5).

ANOVA did not reveal significant difference between responders and failures. However since the number of subjects (samples) was very limited and the number of parameters (genes) was high it was reasonable to pay particular attention to the most significant expression changes of individual miRNAs. We selected miRNAs with individual $p$-value $<0.05-18$ genes (Table 6). We analyzed these miRNAs using DIANA tools [28]. This set of programs allows pathway enrichment analysis with genes, interacting with selected miRNAs.

We found 40 pathways enriched with genes regulated by the selected miRNAs (Additional file 2: Table S2). These differently expressed miRNAs are involved in vital processes in cells including p53 signaling pathway, toll-like receptor signaling pathway, adherence junction, notch signaling pathway, PI3K-Akt signaling pathway, apoptosis, Wnt signaling pathway, MAPK signaling pathway, transcriptional misregulation in cancer and cell cycle. Among these pathways "Pathways in cancer" (hsa05200) has the highest p-value $\left(9.5^{*} 10^{-14}\right)$ with 27 genes regulated by 7 miRNAs. Among other cancer specific pathways one can particularly mention "Chronic myeloid leukemia" (hsa05220) $(p=0.00018)$ with 8 genes regulated by 4 miRNAs and "Acute myeloid leukemia" (hsa05221) ( $p=0.04)$ with 4 genes regulated by 3 miRNAs.

\section{Discussion}

Here we describe our attempts to find molecular predictors of TKI therapy efficacy in primary CML patients based on genetic variants and expression.
We applied Sokal score to the patients included in transcriptome and miRNA analyses and were surprised by the poor prediction of the TKI efficacy. Seventy-three percent ( 8 from 11 patients) were correctly predicted as optimal responders and only 56\% (5 from 9 patients) were correctly predicted as non-responders. Taking together only $65 \%$ of patients in our study were correctly classified based on Sokal score. Sure we clearly understand that our groups are very small for any conclusions about application of Sokal score. But we also understand

Table 6 List of selected miRNAs

\begin{tabular}{llll}
\hline Gene & Accession & Coefficient $^{\mathrm{a}}$ & $p$-value \\
\hline hsa-miR-720 & MIMAT0005954 & -12.31 & 0.04 \\
hsa-miR-1180 & MIMAT0005825 & -8.33 & 0.02 \\
hsa-miR-92a-3p & MIMAT0000092 & -7.58 & 0.03 \\
hsa-miR-409-3p & MIMAT0001639 & -3.06 & 0.03 \\
hsa-miR-331-5p & MIMAT0004700 & -2.68 & 0.01 \\
hsa-miR-662 & MIMAT0003325 & -2.5 & 0.03 \\
hsa-miR-891a & MIMAT0004902 & -2.5 & 0.04 \\
hsa-miR-548ah-5p & MIMAT0018972 & -2.22 & 0.01 \\
hsa-miR-432-5p & MIMAT0002814 & -2.2 & 0.03 \\
hsa-miR-553 & MIMAT0003216 & 1.32 & 0.02 \\
hsa-miR-338-3p & MIMAT0000763 & 2.91 & 0.02 \\
hsa-miR-450a-5p & MIMAT0001545 & 3.29 & 0.03 \\
hsa-miR-145-5p & MIMAT0000437 & 3.48 & 0.01 \\
hsa-miR-324-5p & MIMAT0000761 & 3.8 & 0.03 \\
hsa-miR-181b-5p+hsa-miR-181d & MIMAT0000257 & 4.26 & 0.03 \\
hsa-miR-181a-5p & MIMAT0000256 & 4.29 & 0 \\
hsa-miR-221-3p & MIMAT0000278 & 5.49 & 0.02 \\
hsa-miR-4286 & MIMAT0016916 & 26.46 & 0.01 \\
\hline
\end{tabular}

${ }^{a}$ Coefficients below zero correspond to elevation of miRNA expression in optimal responders and coefficients above zero correspond to elevated miRNA expression in non-optimal responders 
that it is very difficult to rely on the predictive value of this score for the prediction of early treatment efficacy. At the same time there were no patients with borderline values of $\mathrm{BCR}-\mathrm{ABL}^{\mathrm{IS}}$ or $\mathrm{Ph}+$ metaphases in our transcriptome and miRNA study. All responders really responded well to treatment, and non-responders were > $10 \% \mathrm{Ph}+$ cells at 6 months in bone marrow. Therefore, we conducted this study in order to find new molecular predictors of treatment efficacy .

To date, researchers performed several attempts to detect genetic markers associated with resistance to TKI or non-optimal response to targeted therapy. It was shown that the resistance of leukemic cells is associated with the enhanced PI3K/AKT, RAF/MEK/ERK and STAT3 signaling pathways [29]. At the same time, studies involving patients with different responses to TKI, show influence of genetic polymorphisms in TKI metabolizers' genes [9], BIM gene [30], FAS gene [10], DNMT3A and ASXL1 genes [11].

We did not confirm different allelic frequencies in patients with different response to the therapy. This can be explained by the fact that the efficiency of TKI therapy can be affected by a variety of both genetic and environmental factors, making the therapy failure a multifactorial feature.

Previously performed studies showed that the expression profiles in patients with optimal and non-optimal responses to TKI therapy varied widely. For example, as published by Frank et al. in 2006, differential expression of some genes was found in two groups of patients and based on this findings authors made conclusions about the discovery of candidate predictors of imatinib resistance [14]. In another study, published in the same year in the same journal, significant difference in the expression of other genes was showed [15]. Finally, one more work in the same journal demonstrated a third list of genes of potential predictors [31]. All these works were done before the next-generation sequencing era, so we conducted our study to find the expression differences by unbiased analysis of the large number of genes. We found some changes in expression levels, but they were very small and it is inappropriate to further look for changes in some specific genes and to develop prognostic tests on their basis. Additionally, we checked all genes that have been previously mentioned in similar studies to be associated with different responses to TKI therapy. We found no difference in allelic frequencies of these genes in our groups. It is possible that revealing specific activation patterns of the whole pathogenic mechanisms is more promising for diagnostic purposes. Another possible solution is to analyze expression of bone marrow samples, containing more stem cells or direct selection and analysis of cancer stem cells which is however difficult for routine implementation.
We revealed 17 differently expressed miRNAs in patients with optimal and non-optimal responses to TKI therapy. For nowadays miRNA profiling is frequently used to find molecular predictors, treatment targets or biomarkers in cancer. Indeed miRNAs are involved in CML pathogenesis [17-19]. Recently it was shown that miR-92a-3p functions as oncogene blocking apoptosis in AML cells. Inhibition of this miRNA leads to increase of apoptosis in M-07e cell line [32]. Nevertheless in our study patients with optimal response had 8-fold higher expression of miR-92a-3p than non-optimal responders. We revealed 3-fold decrease of miR-331-5p in treatment failures. This finding is in the agreement with previously reported association of low levels of this miRNA in K562 cells with the resistance to doxorubicin [33]. We also found that expression of miR-324-5p was 3.8-fold higher in patients with non-optimal response to TKI which correlates with its elevated expression in patients with poor outcome (progression-free and overall survival) of the diffuse large B-cell lymphoma [34]. Despite such large differences in miRNA expression levels between groups, we did not continue this work due to the absence of significant difference using ANOVA with strict corrections for multiple comparisons.

We didn't sequence $B C R / A B L$ kinase domain in all patients, because these mutations usually develop during treatment and result in the secondary resistance to TKIs while we examined patients with primary TKI resistance. Nevertheless we checked 7 out of 11 patients included in transcriptome and miRNA expression analysis and didn't find mutations in $B C R / A B L$ kinase domain (data not shown).

\section{Conclusions}

In conclusion, using modern high-throughput methods such as whole-exome, transcriptome and miRNA analysis, we could not find reliable molecular markers for early prediction of TKI efficiency in Ph+CML patients. Apparently, efficacy of targeted therapy is determined not only by genetic factors, the environmental component of therapy response also plays a great role. It is necessary to continue search for mechanisms of tumor cells sensitivity to therapy for their complete elimination.

\section{Additional files}

Additional file 1: Table S1. List of primers. (XLSX $10 \mathrm{~kb}$ )

Additional file 2: Table S2. Pathways enriched with genes regulated by the selected miRNAs. (XLSX $11 \mathrm{~kb}$ )

Acknowledgements

We thank A.O. Abdullaev from National Research Center for Hematology (Moscow, Russia) and A.V. Misurin from Genotechnologia (Moscow, Russia) 
for $B C R / A B L$ kinase domain sequencing and A.V. Polyakov' laboratory (Research Centre for Medical Genetics, Moscow, Russia) for Sanger sequencing.

\section{Funding}

Publication costs were funded by Russian Ministry of Education and Science (agreement \# 8113 from 28/08/2012).

\section{Availability of data and materials}

Not applicable

\section{About this supplement}

This article has been published as part of BMC Medical Genomics Volume 12 Supplement 2, 2019: Selected articles from BGRSISB-2018: medical genomics. The full contents of the supplement are available online at https://bmcmed genomics.biomedcentral.com/articles/supplements/volume-12-supplement-2.

\section{Authors' contributions}

AVL, EYC, AGT, SIK designed the study, AVL, SAS, EPA, KSK-N performed experiments, AVL, EPA, KSK-N, VDY, AGT, SIK analyzed results, AVL, SAS, EYC, AGT, SIK wrote the article, EYC, OAS, GAT, SVM, AGT treated patients in clinical trial and collected clinical data. All the authors read and approved the final manuscript.

\section{Ethics approval and consent to participate}

Not applicable

\section{Consent for publication}

Not applicable

\section{Competing interests}

The authors declare that they have no competing interests.

\section{Publisher's Note}

Springer Nature remains neutral with regard to jurisdictional claims in published maps and institutional affiliations.

\begin{abstract}
Author details
${ }^{1}$ Laboratory of Mutagenesis, Federal State Budgetary Institution, Research Centre for Medical Genetics, Moskvorechie str., 1, Moscow, Russian Federation 115522. ${ }^{2}$ Scientific and Advisory Department of Chemotherapy of Myeloproliferative disorders, Federal State-Funded Institution National Research Center for Hematology of the Ministry of Healthcare of the Russian Federation, Novy Zykovki proezd, 4, Moscow, Russian Federation 125167. ${ }^{3}$ Department of Molecular and Cellular Genetics, State Budgetary Educational Institution of Higher Professional Education "Russian National Research Medical University named after N.I. Pirogov" of Ministry of Health of the Russian Federation, Ostrovityanova str., 1, Moscow, Russian Federation 117997. ${ }^{4}$ Regional Children Hospital 1, S. Deryabinoy str., 32, Ekaterinburg, Russian Federation 620149. ${ }^{5}$ Research Institute of Medical Cell Technologies, Soboleva str., 25, Ekaterinburg, Russian Federation 620905. ${ }^{6}$ Federal State Budgetary Educational Institution of Higher Education, Urals State Medical University of the Ministry of Healthcare of the Russian Federation, Repina str., 3, Ekaterinburg, Russian Federation 620028. 'Laboratory of Medical Genetics, The Rostov State Medical University, Nahichevansky av., 29, Rostov-on-Don, Russian Federation 344022.
\end{abstract}

\section{Published: 13 March 2019}

\section{References}

1. Yin W, Penrod JR, Maclean R, Lakdawalla DN, Philipson T. Value of survival gains in chronic myeloid leukemia. Am J Manag Care. 2012;18(Suppl 11): S257-64.

2. Hehlmann $R$, Lauseker M, Saußele $S$, Pfirrmann M, Krause $S$, Kolb HJ, Neubauer A, Hossfeld DK, Nerl C, Gratwohl A, Baerlocher GM, Heim D, Brümmendorf TH, Fabarius A, Haferlach C, Schlegelberger B, Müller MC, Jeromin S, Proetel U, Kohlbrenner K, Voskanyan A, Rinaldetti S, Seifarth W, Spieß B, Balleisen L, Goebeler MC, Hänel M, Ho A, Dengler J, Falge C, Kanz L, Kremers S, Burchert A, Kneba M, Stegelmann F, Köhne CA, Lindemann HW, Waller CF, Pfreundschuh M, Spiekermann K, Berdel WE, Müller L, Edinger M, Mayer J, Beelen DW, Bentz M, Link H, Hertenstein B, Fuchs R, Wernli M, Schlegel F, Schlag R, de Wit M, Trümper L, Hebart
H, Hahn M, Thomalla J, Scheid C, Schafhausen P, Verbeek W, Eckart MJ, Gassmann W, Pezzutto A, Schenk M, Brossart P, Geer T, Bildat S, Schäfer E, Hochhaus A, Hasford J, for the SAKK and the German CML study group. Assessment of imatinib as first-line treatment of chronic myeloid leukemia: 10year survival results of the randomized CML study IV and impact of non-CML determinants. Leukemia. 2017;31:2398-406.

3. Quintás-Cardama A, Kantarjian HM, Cortes JE. Mechanisms of primary and secondary resistance to imatinib in chronic myeloid leukemia. Cancer Control. 2009;16(2):122-31.

4. Iriyama N, Hatta Y, Kobayashi S, Uchino Y, Miura K, Kurita D, Kodaira H, Inoue $M$, Takei $M$. The European treatment and outcome study score is associated with clinical outcomes and treatment response following European LeukemiaNet 2013 recommendations in chronic-phase chronic myeloid leukemia. Int J Hematol. 2014;100(4):379-85.

5. Francis J, Dubashi B, Sundaram R, Pradhan SC, Chandrasekaran A. Influence of Sokal, Hasford, EUTOS scores and pharmacogenetic factors on the complete cytogenetic response at 1 year in chronic myeloid leukemia patients treated with imatinib. Med Oncol. 2015;32(8):213.

6. Yamamoto E, Fujisawa S, Hagihara M, Tanaka M, Fujimaki K, Kishimoto K, Hashimoto C, Itabashi M, Ishibashi D, Nakajima Y, Tachibana T, Kawasaki R, Kuwabara H, Koharazawa H, Yamazaki E, Tomita N, Sakai R, Fujita H, Kanamori $\mathrm{H}$, Ishigatsubo $\mathrm{Y}$. European treatment and outcome study score does not predict imatinib treatment response and outcome in chronic myeloid leukemia patients. Cancer Sci. 2014;105(1):105-9.

7. Hanfstein B, Müller MC, Hochhaus A. Response-related predictors of survival in CML. Ann Hematol. 2015:94(Suppl 2):S227-39.

8. Bixby D, Talpaz M. Seeking the causes and solutions to imatinib-resistance in chronic myeloid leukemia. Leukemia. 2011;25(1):7-22.

9. Angelini $S$, Soverini $S$, Ravegnini G, Barnett M, Turrini E, Thornquist M, Pane F, Hughes TP, White DL, Radich J, Kim DW, Saglio G, Cilloni D, lacobucci I, Perini G, Woodman R, Cantelli-Forti G, Baccarani M, Hrelia P, Martinelli G. Association between imatinib transporters and metabolizing enzymes genotype and response in newly diagnosed chronic myeloid leukemia patients receiving imatinib therapy. Haematologica. 2013;98(2):193-200.

10. Zheng Q, Cao J, Hamad N, Kim HJ, Moon JH, Sohn SK, Jung CW, Lipton JH, Kim DD. Single nucleotide polymorphisms in apoptosis pathway are associated with response to imatinib therapy in chronic myeloid leukemia. J Transl Med. 2016:14:82.

11. Kim T, Tyndel MS, Zhang Z, Ahn J, Choi S, Szardenings M, Lipton JH, Kim HJ, Kim Dong Hwan D. Exome sequencing reveals DNMT3A and ASXL1 variants associate with progression of chronic myeloid leukemia after tyrosine kinase inhibitor therapy. Leuk Res. 2017;59:142-8.

12. Mologni L, Piazza R, Khandelwal P, Pirola A, Gambacorti-Passerini C. Somatic mutations identified at diagnosis by exome sequencing can predict response to imatinib in chronic phase CML patients. Am J Hematol. 2017;92(10):E623-5.

13. Lavrov AV, Chelysheva EY, Smirnikhina SA, Shukhov OA, Turkina AG, Adilgereeva EP, Kutsev SI. Frequent variations in cancer-related genes may play prognostic role in treatment of patients with chronic myeloid leukemia. BMC Genet. 2016;17(Suppl 1):14.

14. Frank O, Brors B, Fabarius A, Li L, Haak M, Merk S, Schwindel U, Zheng C, Müller MC, Gretz N, Hehlmann R, Hochhaus A, Seifarth W. Gene expression signature of primary imatinib-resistant chronic myeloid leukemia patients. Leukemia. 2006;20(8):1400-7.

15. Villuendas R, Steegmann JL, Pollán M, Tracey L, Granda A, Fernández-Ruiz E, Casado LF, Martínez J, Martínez P, Lombardía L, Villalón L, Odriozola J, Piris $M A$. Identification of genes involved in imatinib resistance in CML: a geneexpression profiling approach. Leukemia. 2006;20(6):1047-54.

16. Costa FF. Non-coding RNAs: lost in translation? Gene. 2007;386(1-2):1-10.

17. Rokah OH, Granot G, Ovcharenko A, Modai S, Pasmanik-Chor M, Toren A, Shomron N, Shpilberg O. Downregulation of miR-31, miR-155, and miR-564 in chronic myeloid leukemia cells. PLoS One. 2012;7(4):e35501.

18. Babashah S, Sadeghizadeh M, Tavirani MR, Farivar S, Soleimani M. Aberrant microRNA expression and its implications in the pathogenesis of leukemias. Cell Oncol (Dordr). 2012;35(5):317-34.

19. Fallah P, Amirizadeh N, Poopak B, Toogeh G, Arefian E, Kohram F, Hossein Rad SM, Kohram M, Teimori Naghadeh H, Soleimani M. Expression pattern of key microRNAs in patients with newly diagnosed chronic myeloid leukemia in chronic phase. Int J Lab Hematol. 2015;37(4):560-8.

20. Kotagama $K$, Chang $Y$, Mangone M. miRNAs as biomarkers in chronic myelogenous leukemia. Drug Dev Res. 2015;76(6):278-85. 
21. José-Enériz ES, Román-Gómez J, Jiménez-Velasco A, Garate L, Martin V, Cordeu L, Vilas-Zornoza A, Rodríguez-Otero P, Calasanz MJ, Prósper F, Agirre $X$. MicroRNA expression profiling in Imatinib-resistant chronic myeloid leukemia patients without clinically significant ABL1-mutations. Mol Cancer. 2009;8:69.

22. Jurkovicova D, Lukackova R, Magyerkova M, Kulcsar L, Krivjanska M, Krivjansky V, Chovanec M. microRNA expression profiling as supportive diagnostic and therapy prediction tool in chronic myeloid leukemia. Neoplasma. 2015;62(6):949-58.

23. Hershkovitz-Rokah O, Modai S, Pasmanik-Chor M, Toren A, Shomron N, Raanani P, Shpilberg O, Granot G. MiR-30e induces apoptosis and sensitizes $\mathrm{K} 562$ cells to imatinib treatment via regulation of the BCRABL protein. Cancer Lett. 2015;356(2 Pt B):597-605.

24. Hershkovitz-Rokah O, Modai S, Pasmanik-Chor M, Toren A, Shomron N Raanani P, Shpilberg O, Granot G. Restoration of miR-424 suppresses BCR$A B L$ activity and sensitizes CML cells to imatinib treatment. Cancer Lett. 2015;360(2):245-56.

25. Ferreira AF, Moura LG, Tojal I, Ambrósio L, Pinto-Simões B, Hamerschlak N, Calin GA, Ivan C, Covas DT, Kashima S, Castro FA. ApoptomiRs expression modulated by $B C R-A B L$ is linked to $C M L$ progression and imatinib resistance. Blood Cells Mol Dis. 2014;53(1-2):47-55.

26. Baccarani M, Deininger MW, Rosti G, Hochhaus A, Soverini S, Apperley JF, Cervantes F, Clark RE, Cortes JE, Guilhot F, Hjorth-Hansen H, Hughes TP, Kantarijan HM, Kim DW, Larson RA, Lipton JH, Mahon FX, Martinelli G, Mayer J, Müller MC, Niederwieser D, Pane F, Radich JP, Rousselot P, Saglio G, Saußele S, Schiffer C, Silver R, Simonsson B, Steegmann JL, Goldman JM, Hehlmann R. European LeukemiaNet recommendations for the management of chronic myeloid leukemia: 2013. Blood. 2013;122:872-84.

27. J.P. Sinnwell, D.J. Schaid, Haplo Stats (version 1.7.7) Statistical Methods for Haplotypes When Linkage Phase is Ambiguous [Internet]. Rochester MN USA 55904, Mayo Clinic Division of Health Sciences Research. https://cran.rproject.org/web/packages/haplo.stats/vignettes/manualHaploStats.pdf. Accessed 05 July 2018.

28. Vlachos IS, Kostoulas N, Vergoulis T, Georgakilas G, Reczko M, Maragkakis M, Paraskevopoulou MD, Prionidis K, Dalamagas T, Hatzigeorgiou AG. DIANA miRPath v.2.0: investigating the combinatorial effect of microRNAs in pathways. Nucleic Acids Res. 2012;40(Web Server issue):W498-504

29. Patel $A B, O$ 'Hare $T$, Deininger MW. Mechanisms of resistance to $A B L$ kinase inhibition in chronic myeloid leukemia and the development of next generation ABL kinase inhibitors. Hematol Oncol Clin North Am. 2017; 31(4):589-612.

30. Augis V, Airiau K, Josselin M, Turcq B, Mahon FX, Belloc F. A single nucleotide polymorphism in CBIM is associated with a slower achievement of major molecular response in chronic myeloid leukaemia treated with imatinib. PLoS One. 2013;8(11):e78582.

31. Chung Y-J, Kim T-M, Kim D-W, Namkoong H, Kim HK, Ha S-A, Kim S, Shin SM, Kim JH, Lee YJ, Kang HM, Kim JW. Gene expression signatures associated with the resistance to imatinib. Leukemia. 2006;20:1542-50.

32. Sharifi M, Salehi R. Blockage of miR-92a-3p with locked nucleic acid induces apoptosis and prevents cell proliferation in human acute megakaryoblastic leukemia. Cancer Gene Ther. 2016;23(1):29-35.

33. Feng $D D$, Zhang $H$, Zhang $P$, Zheng $Y S$, Zhang $X J$, Han BW, Luo XQ, Xu L, Zhou H, Qu LH, Chen YQ. Down-regulated miR-331-5p and miR-27a are associated with chemotherapy resistance and relapse in leukaemia. J Cell Mol Med. 2011;15(10):2164-75

34. Lim EL, Trinh DL, Scott DW, Chu A, Krzywinski M, Zhao Y, Robertson AG, Mungall AJ, Schein J, Boyle M, Mottok A, Ennishi D, Johnson NA, Steidl C, Connors JM, Morin RD, Gascoyne RD, Marra MA. Comprehensive miRNA sequence analysis reveals survival differences in diffuse large B-cell lymphoma patients. Genome Biol. 2015;16:18.

Ready to submit your research? Choose BMC and benefit from:

- fast, convenient online submission

- thorough peer review by experienced researchers in your field

- rapid publication on acceptance

- support for research data, including large and complex data types

- gold Open Access which fosters wider collaboration and increased citations

- maximum visibility for your research: over $100 \mathrm{M}$ website views per year

At BMC, research is always in progress.

Learn more biomedcentral.com/submissions 